\title{
Musyarakah Financing Analysis and Mudharabah Financing Against Profitability (ROA)
}

\author{
Dodi Supriyanto ${ }^{1}$, Muhamad Anton Athoillah ${ }^{2}$ \\ dodi.supriyanto@ekuitas.ac.id ${ }^{1}$, antonathoillah@uinsgd.ac.id ${ }^{2}$
}

\author{
STIE Ekuitas Bandung Indonesia ${ }^{1}$, UIN Sunan Gunung Djati Bandung Indonesia ${ }^{2}$
}

\begin{abstract}
Islamic banks offer various financing products for the purpose and types of financing provided accordingly, while minimizing the future risks of financing. This study aims to analyze the influence of Musyarakah and Mudharabah on profitability (ROA) at PT. BJB Syariah Bank 2013-2017. The research method used is descriptive and verification methods. The data used in this study, namely quarterly BJB Sharia Bank financial reports from 2013 to 2017. The results of this study are that Musyarakah partially influences but not significantly to profitability (ROA). Mudharabah contract financing partially has a significant effect on Return on Assets (ROA). Musharaka contract and Mudharabah significantly influence Return on Assets (ROA).
\end{abstract}

Keywords: musyarakah, mudharabah financing and profitability (ROA).

\section{Pendahuluan}

Bank sebagai salah satu pendukung utama dalam kegiatan ekonomi suatu negara, dimana bank dalam membangun perekonomian negara sangatlah penting. Bank syariah lebih mengutamakan prinsip bagi hasil disetiap kegiatan operasinya, baik dalam penghimpunan dana, penyaluran dana (pembiayaan), dan jasa lainnya. Dilihat dari fungsinya, bank syariah sebagai lembaga intermediasi antara pemilik harta (surplus unit) dan pengguna (deficit unit) yang membutuhkan dana serta untuk membantu memperlancar transaksi dalam prinsip Islam [1].

Bank syariah menawarkan berbagai macam produk pembiayaan untuk tujuan dan jenis pembiayaan yang diberikan sesuai, serta meminimalisirkan risiko yang akan datang dari adanya pembiayaan tersebut. Produk pembiayaan ditentukan oleh beberapa kondisi agar pembiayaan yang disalurkan ada dalam prinsip kehati-hatian, dimana risiko pembiayaan dapat dikendalikan dan mampu memberikan profit yang maksimal. Dengan semakin meningkatnya kebutuhan dan keinginan masyarakat yang semakin kompleks, pihak bank harus memenuhi kebutuhan konsumtif maupun produktif karena itu, Bank BJB Syariah menyediakan produk pembiayaan Musyarakah dan Mudharabah. 
Tabel 1 Perkembangan Produk Pembiayaan Bank BJB Syariah Periode 2013-201 (dalam jutaan rupiah)

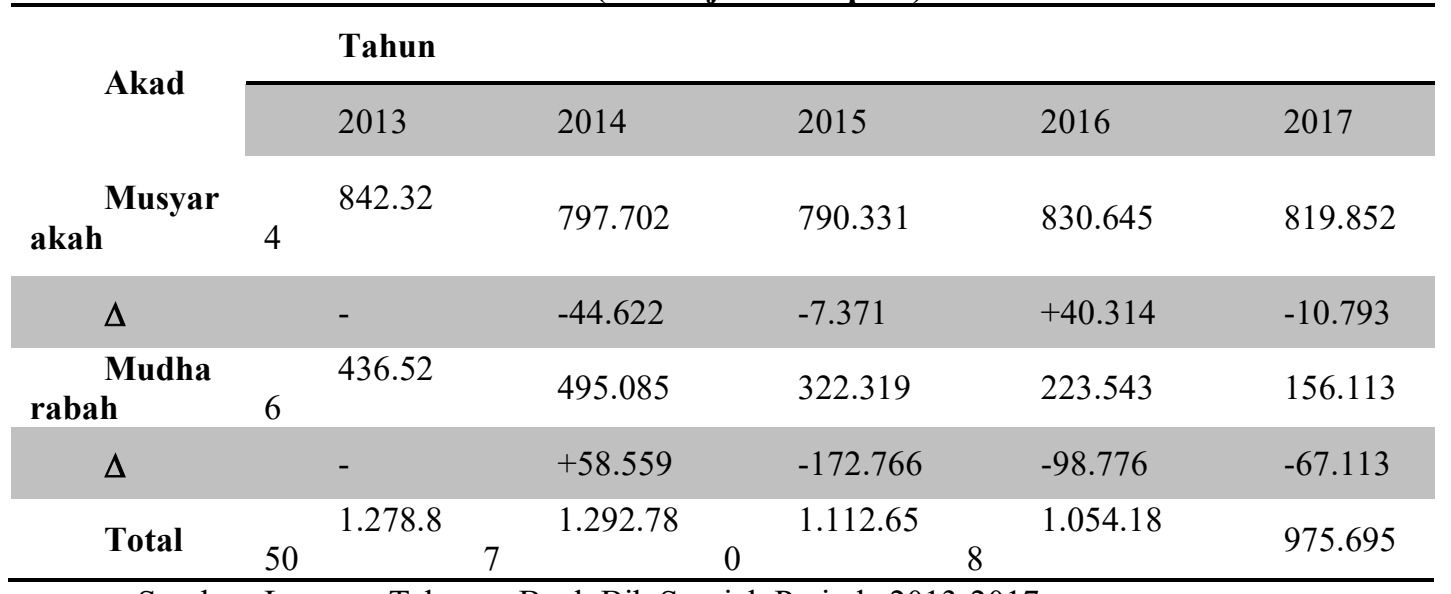

Sumber: Laporan Tahunan Bank Bjb Syariah Periode 2013-2017

Dilihat dari tabel 1.1 diketahui bahwa dari tahun 2013-2017 pembiayaan Musyarakah mengalami fluktuasi secara merata, dan pembiayaan Mudharabah pun terjadi fluktuasi yang cenderung menurun setiap periodenya. Hal ini disebabkan kebutuhan masyarakat dalam pembiayaan yang berubah setiap tahunnya serta dipengaruhi oleh kualitas pembiayaan Musyarakah serta kebutuhan akan pembiayaan yang berubah setiap tahunnyadan pembiayaan Mudharabah kurang baik dan terjadinya pengalihan kepada pembiayaan lain serta dipengaruhi oleh kebijakan PT. Bank BJB Syariah itu sendiri. Penurunan dan fluktuasi ini dalam penyaluran pembiayaan Musyarakah dan Mudharabah pada akhirnya akan memengaruhi pendapatan.

Untuk menilai kondisi keuangan dan kinerja suatu bank syariah, dibutuhkan suatu ukuran. Ukuran profitabilitas dapat menggunakan pendekatan Ratio, salah satunya Return On Assets (ROA). Nilai ROA sebuah bank syariah tinggi, maka profit yang dihasilkan tinggi pula dari penggunaan aset dan memanfaatkan aset yang dimilikinya. [2] BJB Syariah.

Berikut data salah satu rasio untuk mengukur profitabilitas bank yaitu Ratio ROA PT.

Tabel 1 Trend Ratio BJB Syariah Periode 2013-2017

\begin{tabular}{|c|c|c|c|}
\hline n & Tahu & ROA & Perkembangan \\
\hline & 2013 & $0,91 \%$ & - \\
\hline & 2014 & $0,72 \%$ & $-0.19 \%$ \\
\hline & 2015 & $0,25 \%$ & $-0.47 \%$ \\
\hline & 2016 & $-8,09 \%$ & $-8,34 \%$ \\
\hline & 2017 & $-5,69 \%$ & $-2,4 \%$ \\
\hline
\end{tabular}

Sumber: Laporan Tahunan BJB Syariah Periode 2013-2017 (diolah kembali) 
Pada tabel 2 diatas, bahwa perkembangan profitabilitas Bank BJB Syariah diukur dari ROA pada lima tahun secara berurutan mengalami naik turun. Merujuk pada SE.BI No.13/24/DPNP, tentang ketentuan Return On Asset bahwa nilai ROA yang baik untuk sebuah bank adalah 1,5\%. Artinya, jika bank mendapatkan profit dibawah 1,5\% yang ditetepkan oleh BI, maka bank itu belum maksimal dalam mengelola asetnya. Hal tersebut dapat menjadi permasalah bagi Bank BJB Syariah, rasio ini dinilai tidak baik karena kurang dari $1,5 \%$, angka rasio diatas menunjukan bahwa keuntungan dari pengelolaan aset masih kurang optimal sehingga pendapatan turun yang diikuti juga aset menurun, dan untuk memasuki angka 1,5\% belum cukup sehingga Bank BJB Syariah harus memperhatikan pendapatan dari pendapatan pembiayaan lain.[3]

Penelitian yang telah dilakukan oleh Adiya dan Nugroho (2016) berkesimpulan bahwa pembiayaan mudharabah berpengaruh signikan pada profitabilitas Bank Umum Syariah, dan pembiayaan musyarakah tidak berpengaruh signifikan terhadap profitabilitas Bank Umum Syariah. Lebih jauh lagi Adiya dan Nugroho menyatakan hasil penelitian keseluruhan atas mudharabah dan pembiayaan musyarakah berpengaruh signifikan pada profitabilitas Bank Umum Syariah. [4]

\section{Metode}

Dengan metode penelitian deskriftif-verifikatif ini akan didapat hubungan antar variabel lainnya, akhirnya dapat memberikan kesimpulan yang dapat menggambarkan tentang objek yang diteliti. Data yang dijadikan bahan penelitian ini yaitu laporan keuangan PT. BJB Syariah, sumber data diperoleh dari www.bjbsyariah.co.id. [5] Sampel dalam penelitian ini yaitu Pembiayaan Musyarakah (X1), Pembiayaan Mudharabah (X2), dan Return On Assets (Y). Data yang terkait setelah terkumpul kemudian diolah dan dianalisis menggunakan SPSS 25 , dengan alat yang digunakan untuk menganalisis tersebut.

\section{Pembahasan} 2013-2017

Perkembangan Pembiayaan Musyarakah Pada PT. Bank BJB Syariah Periode

Pertumbuhan dan perkembangan pembiayaan Musyarakah, digambarkan dalam grafik seperti berikut.

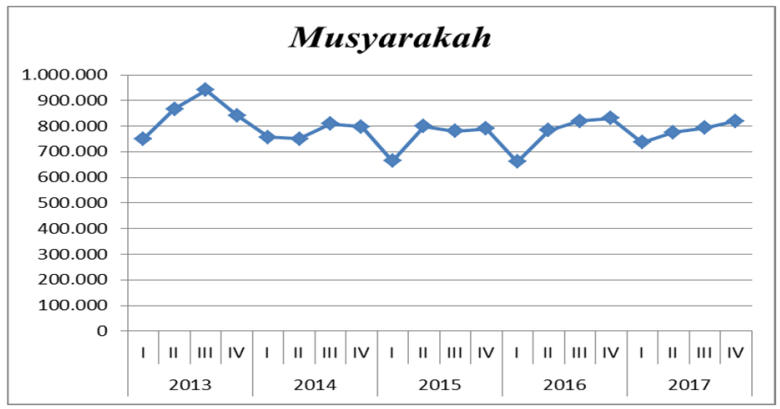

Gambar 1 Grafik Pembiayaan Musyarakah PT. Bank BJB Syariah periode 2013-2017

Sumber: diolah kembali, penulis (2018) 
Gambar 1 menunjukan bahwa pembiayaan musyarakah PT. Bank BJB Syariah tahun 2013-2017 menunjukan fluktuasi secara merata pada setiap triwulannya. Hal ini terjadi karena kebutuhan masyarakat akan pembiayaan yang berubah setiap tahunnya serta dipengaruhi oleh kualitas pembiayaan itu sendiri dan kebijakan PT. Bank BJB Syariah itu sendiri.

Perkembangan Pembiayaan Mudharabah PT. Bank BJB Syariah tahun 2013-2017 berikut:

Perkembangan pembiayaan Mudharabah, dapat ditunjukan pada grafik sebagai



\section{Gambar 2 Grafik Pembiayaan Mudharabah PT. Bank BJB Syariah \\ Tahun 2013-2017}

Sumber: Diolah kembali, penulis (2018)

Grafik 2 menunjukan bahwa pembiayaan Mudharabah PT. Bank BJB Syariah tahun 2013-2017 per-triwulan mengalami berfluktuasi cenderung menurun pada setiap triwulannya. Hal ini terjadi karena pembiayaan Mudharabah kurang populer dan bank kurang menyosialisasikan pembiayaan Mudharabah sehingga nasabah tidak melirik dan tidak berminat dengan pembiayaan ini dam terjadinya pengalihan pembiayaan kepada pembiayaan yang lain.

\section{Perkembangan Ratio ROA PT. Bank BJB Syariah Tahun 2013-2017}

Perkembangan ratio profitabilitas (ROA), dapat ditunjukan dalam bentuk grafik sebagai berikut:

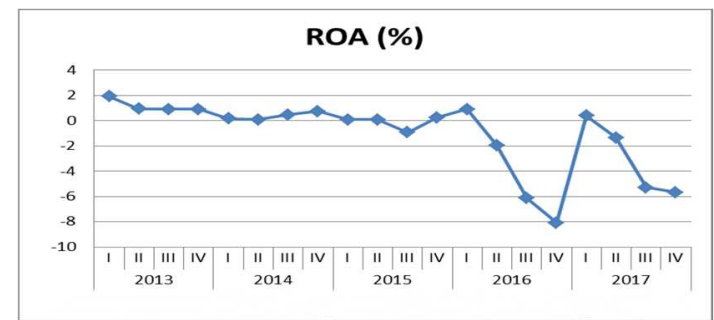

Gambar 3 Grafik Profitabilitas (ROA) PT. Bank BJB Syariah, tahun 2013-2017

Sumber: Data diolah penulis (2018)

Gambar 3 diatas menunjukan tentang perkembangan ratio Return On Assets (ROA) yang terus berfluktuatif menurun. Hal ini terjadi karena tidak konsisten PT. Bank BJB Syariah dalam meningkatkan profitabilitas dari tahun 2013-2017. Salah satu penyebab menurunnya profitabilitas (ROA) adalah karena adanya NPF bermasalah, pembiayaan yang disalurkan tidak diimbangi dengan kualitas sehingga ROA menurun dan tingginya pembentukaan PPAP. 
Mengacu pada SE. BI No.13/24/DPNP, perihal ketentuan ROA minimal, maka ROA yang ideal bagi bank adalah 1,5\%. Return On Assets (ROA) yang dihasilkan PT. BJB Syariah tahun 2013 sampai tahun 2017 kisaran antara -8,09\% sampai dengan 1,92\%. Artinya ratio ROA ini perlu adanya upaya bank untuk ditingkatkan. Bank dinyatakan sehat adalah yang bisa menghasilkan ratio ROA sama dengan standar BI, bila perlu di atas standar yang diberikan BI, hal ini dimaksudkan supaya PT.BJB Syariah dapat meningkatkan upaya yang lebih baik dalam hal menghasilkan profitabilitas. [6]

\section{UJI NORMALITAS}

Berikut ini merupakan gambar dari uji normalitas yang disajikan sebagai berikut:

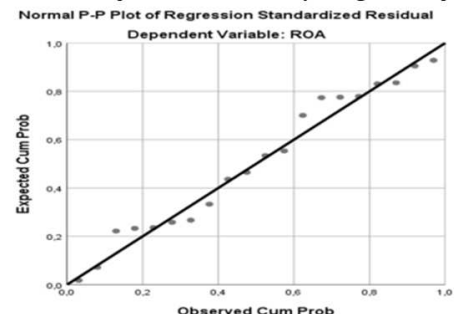

\section{Gambar 4 Uji Normalitas dengan Normal P-Plot}

Sumber : Data diolah penulis, 2018

Grafik Uji Normalitas tersebut, menyatakan titik-titik yang berada di area garis diagonal dan searah garis diagonal menggambarkan pola berdistribusi normal, karena itu model regresi ini merupakan asumsi normalitas.

Di bawah ini hasil pengujian model One Sample Kolmogorov-Smirnov, yang ditunjukan pada tabel sebagai berikut:

\section{Tabel 3 Uji Normalitas}

\begin{tabular}{lll} 
& & Residual Tidak Standar \\
\hline \multicolumn{1}{c}{$\mathrm{N}$} & & 20 \\
\hline Parameter Normal & & \\
& Arti &, 0000000 \\
& $\begin{array}{l}\text { Std. } \\
\text { Deviasi }\end{array}$ &, 02114636 \\
\hline Perbedaan yg lebih ekstrim & Mutlak &, 137 \\
\cline { 2 - 3 } & Positif &, 095 \\
\cline { 2 - 3 } & Negatif &,- 137 \\
\hline Tes Statistik & &, 137 \\
\hline Asymp. Sig. (2-tailed) & &, $200^{\text {c,d }}$ \\
\hline
\end{tabular}

a. Tes distribusi Normal.

b. Perhitungan data.

c. Signifikansi tingkat kesalahan.

d. Ini adalah batas bawah dari signifikansi sejati.

Sumber: Data diolah penulis, 2018 
Tabel 3 di atas menunjukan, uji normalitas dengan menggunakan uji One Sample Kolmogorov-Smirnov sebesar 0,200. Hasil di atas signifikansi sebesar yaitu $0.200>0,05$, sehingga data berdistribusi normal dan merupakan asumsi normalitas.

\section{UJI MULTIKOLINEARITAS}

Data di bawah ini hasil pengujian dengan metode multikolinearitas, sebagai berikut:

Tabel 4 Hasil Koefisien Multikolinearitas



a. Variabel Tergantung : ROA

Sumber: Data diolah penulis, 2018

Tabel di atas menjelaskan hasil uji dengan metode multikolinearitas memiliki nilai Tolaran dari variabel Musyarakah dan Mudharabah sebesar 0,997 > 0,1. Nilai VIF dari variabel Musyarakah dan Mudharabah sebesar $1,003<10$. Hal itu disebut tidak ada nilai multikolinearitas diantara variabel bebas (independen).

\section{UJI AUTOKORELASI}

Tabel 5 adalah hasil uji autokolerasi.

\section{Tabel 5 Autokorelasi}

\begin{tabular}{ll} 
& Sisa Tidak Standar \\
\hline est Value $^{\mathrm{a}}$ &,- 00003 \\
\hline Kasus $<$ Nilai Tes & 10 \\
\hline Kasus $>=$ Nilai Tes & 10 \\
\hline Total Kasus & 20 \\
\hline Jumlah Putaran & 8 \\
\hline Z & $-1,149$ \\
\hline Asymp. Sig. (2-tailed) &, 251 \\
\hline
\end{tabular}
a. Sedang

Sumber: Data diolah penulis, 2018

Tabel 5 merupakan hasil autokorelasi dengan metode Runs Test memiliki nilai Asymp.Sig sebesar 0,251; hasil ini telah menghasilkan nilai Asymp.Sig yaitu 0,251>0,05. Oleh sebab itu, dapat diartikan, tidak ada autokorelasi.

\section{UJI HETEROSKEDASTISITAS}

Gambar 5 di bawah ini merupakan hasil pengujian heteroskedastisitas. 


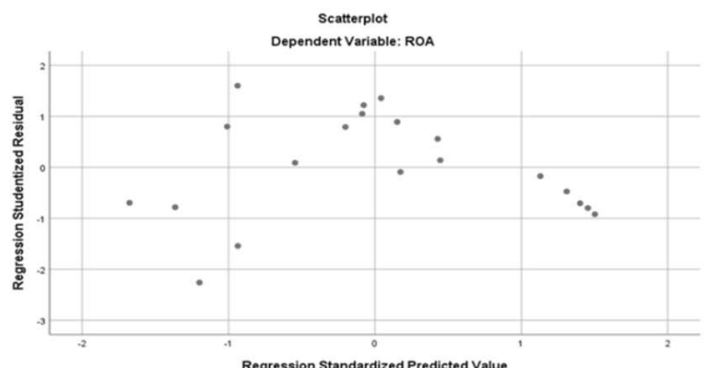

Gambar 4 Grafik Scatterplot

Sumber: Data diolah penulis, 2018

Gambar 5, menjelaskan posisi titik-titik tersebar secara acak. Titik-titik berada di atas dan di bawah angka 0 pada sumbu Y. Karena itu, dikatakan tidak terjadi heteroskedastisitas.

\section{ANALISIS LINEAR BERGANDA}

Analisis ini merupakan suatu model teknik regresi linier dimana variabel tergantungnya merupakan fungsi linear dari variabel bebas.

\section{Coefficients $^{\mathrm{a}}$}

\section{Tabel 6 Hasil Linear Regresi Berganda}

\begin{tabular}{|c|c|c|c|c|c|c|}
\hline \multicolumn{2}{|c|}{ Model } & \multicolumn{2}{|c|}{$\begin{array}{c}\text { Koefisien Tidak Standar } \\
\text { Standar }\end{array}$} & $\begin{array}{l}\text { Koefisien } \\
\text { Standar } \\
\\
\text { Beta }\end{array}$ & $\mathrm{t}$ & Signifikan \\
\hline \multirow[t]{3}{*}{1} & (Konstanta) & & & & ,255 &, 802 \\
\hline & Musyarakah & $-1,017$ & &,- 224 & $-1,247$ & ,229 \\
\hline & Mudharabah & 1,520 & &, 645 & 3,583 &, 002 \\
\hline
\end{tabular}

a. Varibel Tergantung : ROA

Sumber: Data diolah penulis, 2018

Data tabel 6 tersebut dapat dimasukan pada rumus regresi linear berganda dibawah ini.

$$
\mathrm{Y}=0,017-1,017 \mathrm{X}_{1}+1,520 \mathrm{X}_{2}
$$

Persamaan tersebut menghasilkan :

1. Nilai konstanta (a) sebesar 0,017. artinya ketika variabel bebas pembiayaan Musyarakah $\left(\mathrm{X}_{1}\right)$ dan Mudharabah $\left(\mathrm{X}_{2}\right)$ nilainya nol $(0)$, maka Profitabilitas (ROA) nilainya $0.017 \%$.

2. Bila nilai koefisien regresi variabel pembiayaan Musyarakah $\left(X_{1}\right)$ sebesar $-1,017$, artinya ini tidak terdapat hubungan searah dengan pembiayaan Musyarakah dan pengembalian aset (Y); jika terjadi kenaikan 1\% pembiayaan Musyarakah, berarti mengurangi Pengembalian Aset (Y) sebesar 1,017\%.

3. Nilai koefisien regresi variabel pembiayaan Mudharabah $\left(\mathrm{X}_{2}\right)$ bernilai 1,520, artinya nilainya positif. Kondisi ini menunjukkan adanya hubungan yang searah antara pembiayaan Mudharabah $\left(\mathrm{X}_{2}\right)$ dengan Profitabilitas ROA (Y), berarti setiap terjadi 
peningkatan 1\% pembiayaan Mudharabah akan meningkatkan Profitabilitas ROA (Y) sebesar 1,520\%.

\section{KOEFISIENSI KORELASI(R) DAN KOEFISIENSI DETERMINASI $\left(\mathbf{R}^{2}\right)$}

Berikut hasil Koefisiensi Kolerasi (R) dan Koefisiensi Determinasi ( $\left.{ }^{2}\right)$.

Tabel 7 Hasil Koefisiensi Kolerasi (R) dan Koefisiensi Determinasi $\left(\mathbf{R}^{2}\right)$, Ringkasan Model Mode

\begin{tabular}{cll|ccc}
1 & $\mathrm{R}$ & R Kotak & Kotak & dari Perkiraan & Durbin-Watson \\
\hline 1 &, $672^{\mathrm{a}}$ &, 451 &, 386 &, 0223557 & 1,323 \\
\hline
\end{tabular}

a. Prediktor: (Konstan), Mudharabah, Musyarakah

b. Variabel Tergantung: ROA

Sumber: Data diolah penulis, 2018

Tabel 7 menunjukkan angka koefisien sebesar 0,672. Nilai koefisien berada di interval koefisien 0,60 - 0,799, terdapat hubungan yang kuat. Mengacu kepada pedoman interprestasi terhadap koefisien korelasi, maka diperoleh angka R-Kotak sebesar 0,451 atau 45,1\%. Kedua variabel bebas itu, pembiayaan Musyarakah dan Mudharabah berkontribusi senilai 45,1\% pada Profitiabilitas (ROA) PT. BJB Syariah tahun 2013-2017, sisanya sebesar $54,9 \%$ dipengaruhi faktor lain.

\section{UJI T}

Guna menguji dugaan sementara yang terpisah (parsial) yaitu $\mathrm{X}_{1}$ dan $\mathrm{Y}$ serta $\mathrm{X}_{2}$ dan $\mathrm{Y}$, adalah sebagai berikut.

Coefficients $^{\mathrm{a}}$

$$
\text { Tabel } 8 \text { Hasil Uji Terpisah (Uji-t) }
$$

\begin{tabular}{|c|c|c|c|c|c|c|}
\hline \multicolumn{2}{|c|}{ Model } & 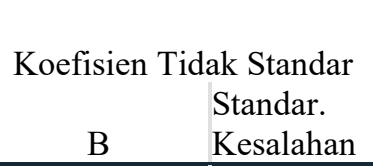 & & $\begin{array}{l}\text { Koefisien } \\
\text { Standar } \\
\text { Beta }\end{array}$ & \multirow{2}{*}{$T_{255}$} & Sig. \\
\hline 1 & (Konstan) &, 017 & \multicolumn{2}{|l|}{, 065} & &, 255 \\
\hline & Musyarakah & $-1,017 \mathrm{E}-7$ &, 000 &,- 224 & \multirow{2}{*}{$\begin{array}{r}-1,247 \\
583\end{array}$} & ,229 \\
\hline & Mudharabah & $1,520 \mathrm{E}-7$ &, 000 &, 645 & &, 002 \\
\hline
\end{tabular}

a. Variabel Tergantung: ROA

Sumber: Data diolah penulis, 2018

Tabel 8 menunjukkan hasil pembiayaan Musyarakah nilai $t_{\text {hitung }} \leq \mathrm{t}_{\text {tabel }}$ sebesar $-1,247$ $\leq 2,110$ (df (n-k) $20-3=17, \alpha=0,05$ ). Tingkat signifikansi 0,229, artinya angka signifikan lebih besar dari 0,05. Hasil uji tersebut diatas, menghasilkan Ho diterima, artinya bahwa pembiayaan Musyarakah $\left(\mathrm{X}_{1}\right)$ secara parsial tidak berpengaruh signifikan pada Profitabilitas (ROA) (Y).

Sedangkan Mudharabah diketahui nilai $t_{\text {hitung }} \geq t_{\text {tabel }}$ sebesar 3,583 $\geq 2,110$ dan tingkat signifikansi 0,002 , artinya nilai itu kurang dari 0,05 . Hasil pengujian diatas menghasilkan Ho ditolak, artinya pembiayaan Mudharabah $\left(\mathrm{X}_{2}\right)$ secara parsial ada berpengaruh yang signifikan pada profitabilitas (ROA) (Y).

\section{UJI F}

Uji f statistik menghasilkan jika semua variabel mandiri (bebas) mempunyai pengaruh simultan pada variabel tergantung (terikat). 


\begin{tabular}{|c|c|c|c|c|c|c|}
\hline \multicolumn{7}{|c|}{ [asil Simultan (Uji-f) } \\
\hline \multicolumn{2}{|c|}{ Model } & $\begin{array}{l}\text { Ringkasan } \\
\text { dari Kotak }\end{array}$ & Df & $\begin{array}{l}\text { Mean } \\
\text { Kotak }\end{array}$ & \multirow{2}{*}{$\frac{F}{6,981}$} & \multirow{2}{*}{$\frac{\text { Sig. }}{, 006^{\mathrm{b}}}$} \\
\hline 1 & Regression &, 007 & 2 &, 003 & & \\
\hline & Residual & ,008 & 17 & ,000 & & \\
\hline & Total &, 015 & 19 & & & \\
\hline
\end{tabular}

a. Variabel Tergantung : ROA

b. Prediktor: (Konstan), Mudharabah, Musyarakah

Sumber: Data diolah penulis, 2018

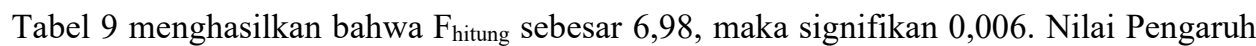
signifikansi di bawah 0,05 sedangkan nilai $F_{\text {tabel }}$ sebesar 3,59 [(df $\left.(\mathrm{n} 1)=\mathrm{k}-1\right)(\mathrm{df}(\mathrm{n} 1)=3-1$ $=2)][\mathrm{df}(\mathrm{n} 2)=\mathrm{n}-\mathrm{k})(\mathrm{df}(\mathrm{n} 2)=20-3=17)$ sehingga nilai $F_{\text {hitung }}$ sebesar $6,981 \geq \mathrm{F}_{\text {tabel }}$ sebesar 3,59 artinya bahwa Ho ditolak dan Ha diterima, dimana ada hubungan yang signifikan antara variabel pembiayaan Musyarakah $\left(\mathrm{X}_{1}\right)$ dan Mudharabah $\left(\mathrm{X}_{2}\right)$ secara simultan pada Profitabilitas (ROA) (Y).

\section{Kesimpulan}

1. Perkembangan pembiayaan Musyarakah pada PT. Bank BJB Syariah periode 2013-2017 mengalami fluktuasi secara merata setiap triwulannya. Kenaikan terbesar pembiayaan Musyarakah terjadi tahun 2015 triwulan kedua sebesar 134.838 juta rupiah. Sedangkan pembiayaan Musyarakah terendah terjadi tahun 2015 triwulan kesatu sebesar -133.721 jutaan rupiah. Di sisi lain, pembiayaan Mudharabah PT. Bank BJB Syariah tahun 20132017 fluktuatif dan cenderung menurun setiap triwulannya. Kenaikan terbesar pembiayaan Mudharabah terjadi pada tahun 2014 triwulan kesatu sebesar 65.613 juta rupiah. Sedangkan perkembangan pembiayaan Mudharabah terrendah terjadi pada tahun 2015 triwulan III sebesar -46.133 jutaan rupiah .

2. Perkembangan Reutrn On Asset PT. BJB Syariah tahun 2013-2017 mengalami fluktuasi setiap triwulannya. Kenaikan terbesar ROA terjadi tahun 2017 pada triwulan I sebesar $8,48 \%$ Sedangkan perkembangan ROAterrendah terjadi pada tahun 2014 triwulan III sebesar -4,21\%. Rata-rata ROA pada tahun 2013-2017 sebesar -1,0855 hal ini menunjukkan ROA tidak optimal dibandingankan standar yang ditetapkan BI dengan SE No. 13/24/DPNP sebesar 1,5\%.

3. Pembiayaan Musyarakah dan Mudharabah pada Pengembalian Aset PT. BJB Syariah tahun 2013 sampai tahun 2017 dapat dinyatakan :

a. Pembiayaan Musyarakah secara parsial tidak berpengaruh signifikan pada pengembalian asset. Untuk pembiayaan mudharabah mempunyai pengaruh signifikan pada pengembalian aset.

b. Musyarakah dan Mudharabah secara simultan berpengaruh signifikansi terhadap Return On Asset. 


\section{References}

[1] Yani, A., Yanti, B. dan Mayasari, E. (2017), Analis Pengaruh Capital Adequacy Ratio (CAR), Non performing Financing (NPF), Financing To Deposit Ratio (FDR) dan Biaya Operasional/Pendapatan Operasional (BOPO) Terhadap Return On Assets (ROA) (Studi Kasus pada Bank Umum Syariah Indonesia Tahun 2011-2015), Jurnal Manajemen dan Kewirausahaan, Vol.8, No.3.

[2] Atang. (2011), Fiqih Perbankan Syariah: Transformasi Fiqih Muamalah ke dalam Peraturan Perundang-undangan, Bandung: PT Refika Aditama.

[3] Surat Edaran Bank Indonesia Nomor 13/24/DPNP tentang Perihal Penilaian Tingkat Kesehatan Bank Umum.

[4] Aditya, R. dan Nugroho, A. (2015), Pengaruh Pembiayaan Mudharabah dan Pembiayaan Musyarakah Terhadap Tingkat Profitabilitas Bank Umum Syariah Periode 2010-2014, Jurnal Profita, Vol 4, hlm 2-10.

[5] http://www.bjbsyariah.co.id, diunduh pada tanggal 05 Oktober 2018.

[6] Surat Edaran Bank Indonesia Nomor 13/24/DPNP tentang Perihal Penilaian Tingkat Kesehatan Bank Umum 